\title{
Prevention of Environmental Triggers in Allergic Diseases
}

\author{
AB Singh* \\ CSIR-Institute of Genomics and Integrative Biology, India
}

Submission: March 09, 2018; Published: March 15, 2018

*Corresponding author: AB Singh, Emeritus Scientist (Ex), CSIR- Institute of Genomics and Integrative Biology, Delhi University, Campus , Delhi, Tel: 919811554462; Email: singha49@hotmail.com

\section{Introduction}

A wide range of epidemiological and experimental studies have contributed to major advances in the field of allergic diseases. A variety of risk factors play a multifaceted role, in secondary prevention of allergy. Identification of allergy triggers forms the actual basis of secondary environmental prevention. These triggers include both indoor allergens such as house dust mites, molds, pets, cockroaches etc. and outdoor allergens such as pollen grains, melds, plant debris etc. Molds and their metabolites are considered to be triggers of respiratory allergy Pets, dogs, cats are well known to trigger allergic symptoms in sensitized subjects. Outdoor molds may trigger allergy and asthma acerbations. Amongst outdoor allergens pollen are important triggers of seasonal allergy symptoms such as allergic rhinitis, atopic dermatitis and asthma [1].

\section{Indoor Alergens}

\section{House dust mites' allergens (HDM)}

HDM allergens are ubiquitous pyroglyphidae that are commonly found in human dwellings. These mites grow best with higher indoor humidity and elevated temperatures. Involvement of mites as triggers of allergy and asthma includes an association between HDM allergen exposure and patients $[2,3]$. There have been several studies on avoidance procedures with respect to mite allergens $[4,5]$. Four meta-analyses on HDM allergen avoidance by Gotzsche and Johnsen concluded that avoidance was of no benefit to asthmatic/allergic patients [6]. Further, Custovic and Wij concluded inadequate evidence to advocate avoidance in adults but have some benefit in children [7]. However Platt Mills criticized the method of meta-analysis as allergen avoidance protocols are multipronged and personalized [8]. Dusts collected from houses of patients include many more contaminants beside mites as molds, bacteria, endotoxins, fungal glucans, mycotoxins, pollen, insect derived materials etc $[9,10]$. Thus house dust avoidance procedures aimed directly on HDMs may only provide partial benefit to sensitized patients.

\section{Molds (Fungi) Avoidance}

Among indoor triggers fungi or molds are important microorganisms in patients' dwellings. Although there are thousands of fungal species but avoidance to 60-80 molds are considered allergenically important. There is direct association between dampness and mold proliferation leading to health impacts. The association between dampness and molds in houses has been reviewed by Cox Gamser [11]. In UK randomized controlled study, allergy symptoms and medications use declined in an interventional group as compared to control group.

\section{Avoidance to Pets}

It is estimated that $\sim 50 \%$ of families in developed countries have pets $[12,13]$, so is the case of families with allergies. Cats are important triggers of allergic symptoms [14]. Allergy to pets can be readily documented based on clinical history. Allergic particles from pets are small ranging from 2-10 $\mu$ size which allows them to be airborne and even stick to cloths of sensitized subjects and floors. Although removal of cats from patients have may minimize their exposure, but may encounter from other locations as it is ubiquitous $[15,16]$. When the cast remain in the house, basic avoidance measures do not help in decrease of Pet allergen levels $[17,18]$. Dog allergens are found in dog hairs, skin cells, saliva and urine. Dog allergy is less common as compared to cats and avoidance measures do not help much.

\section{Cockroach allergens}

Cockroach allergens are mostly found in kitchen with lower and middle class houses. Allergy and asthma are associated with cockroach allergen exposure [19]. It is observed that strategies that reduce cockroach allergen by environmental management are clinically beneficial to patients [20]. A Joint Task Force on environmental management of cockroaches has recently been summarized by major professional organizations [21]. The environmental measures include clean kitchens, timely washing of utensils, keeping food items in closed containers, frequent disposal of garbage, setting of cockroach traps and chemicals \& sprays etc.

\section{Outdoor Allergens:}

a. Pollen Allergens: Environmental management of pollen is relevant during their pollen seasons particularly that are airborne and are important as allergens. During the pollen 
period, patients are advised to (if possible) to be outdoor during early morning before sunrise and during the late afternoon. In addition to this, door and home windows should be kept shut to reduce pollen exposure from air. Patients are further advised to use air conditioner, use pollen mask, and use showers after coming from outdoors. Patients also advised to cover their hairs for a long period during outdoors. Although there are common suggestions to minimise pollen exposure but these have not been validated scientifically.

b. Outdoor Moulds: Some of the fungi considered allergenically important as outdoor allergens are Alternaria, Cladosporium and Fusarium. However, some of the aerophilic species such as Pennicilliums \& Aspergillus are indoor allergens causing allergic diseases. Compared to indoor allergens, the diagnosis of outdoor mould allergy is difficult due to non-availability of standardized mold allergen extracts. These fungi also have greater cross reactivity with even taxonomically unrelated species.

\section{Smoking}

a. Passive smoking: It is well established that passive smoking is associated with aggravation of asthma \& allergy with increased hospitalization [22]. The implementation of public ban on smoking has been observed to have reduced exacerbation of asthma [23,24]. A meta-analysis of 11 studies published between 2008 to 2013 reported $10 \%$ reduction in hospital admission after smoke ban [25].

b. Air Pollution: Avoidance of outdoor air pollution is very hard to achieve because there is no realistic way for avoidance their exposure. In children with moderate asthma/ allergy have decreased lung function. Many regulatory agencies recommend that allergic patients may remain indoors during high pollution to avoid exposure to clinical and organic volatile substances. However, some believe indoor air pollution is also equally harmful to susceptible individuals. When air quality index reaches certain harmful level, all patients should avoid outdoor exposure and reduce the time in outdoor air [26]. Many organizations recommend wearing dust mask and taking antioxidants which may not be very effective [27]. Therefore, sustained clean air remains the most effective way to reduce health effects of respiratory allergy patients that are pollutant related.

\section{Weather Parameters}

In general, the effect of cold temperature triggers asthma symptoms \& hospital visit, so is the ease of increasing temperature and increase in emergency visits particularly by elderly patients [28]. High altitude has been well known to be associated with reduced mite exposure leading to reduced sensitization rate to mites [29]. However recent studies suggest that reduced allergy in high altitude could be due to overall reduction of pollen and molds leading to reduced exposure of outdoor allergens.

\section{Stress and Emotional constrains}

Stress enhances the airway inflammation by modulating immune cell function. Psychological triggers have been consistently associated with exacerbation and emergency visits [30]. Anxiety may exacerbate the effects of disrupted steep on childhood asthma [31].

\section{Recommendation from Professional Organisations}

Recommendation by National Societies in the identification and managements of triggers vary widely. US guidelines for management of allergy \& asthma suggest trigger identification and avoidance instructions. The British Thoracic Society also recommends identification of triggers and emphasize on the role of passive smoking. The French Society of Pulmonology provides a list of triggers. The American Academy of Allergy also recommends avoiding triggers. However, with respect to allergen avoidance there are discrepancies in their recommendations. The British Society does not recommend the use physical and clinical methods for reducing HDM allergen levels in the home and concludes that single interventions have very limited or no effect. However, the British Society of Allergy and Clinical Immunology advocate that avoidance of HDM may be beneficial in highly motivated allergy patients with multiple interventions. The ARIA guide line suggested not using single clinical or physical preventing method of avoidance but to use combinations.

\section{Summary}

To summarize the natural history of allergy and asthma are influenced by many triggers of allergenic and non-allergenic origin. Educational programmes should focus on patient's questions to address triggers. In many situations the avoidance of triggers does not provide guarantee for success and multifaceted approach. It must be adopted in avoidance strategies.

\section{References}

1. Gent JF, Belanger K, Triche EW, Bracken MB, Beckett WS, et al. (2009) Association of pediatric asthma severity with exposure to common household dust allergens. Environ Res 109(6): 768-774.

2. Gent JF, Kezik JM, Hill ME, Tsai E, Li DW, et al. (2012) Household mold and dust allergens: exposure, sensitization and childhood asthma morbidity. Environ Res 118(10): 86-93.

3. Hammarquist C, Burr ML, Gotzsche PC (2008) House dust mite control measures for asthma. Cochrane Database Syst Rev 2: CD001187.

4. Custovic A, Wijk PG (2005) The effectiveness of measures to change the indoor environment in the treatment of allergic rhinitis and asthma: ARIA update (in collaboration with GA(2)LEN). Allergy 60(9): 1112-1115.

5. Platts Mills TA (2008) Allergen avoidance in the treatment of asthma: problems with the meta-analyses. J Allergy Clin Immunol 122(4): 694696.

6. Nevalainen A, Täubel M, Hyärinen A (2015) Indoorfungi: companions and contaminants. Indoor Air 25(2): 125-156.

7. Cox Ganser JM (2015) Indoor dampness and mould health effectsongoing questions on microbial exposures and allergic versus nonallergic mechanisms. Clin Exp Allergy 45(10): 1478-1482. 
8. National Pet Owners Survey 2009-2010. American Pet Products Association (APPA), USA.

9. Facts and Figures (2012) The European Pet Food Industry Federation (FEDIAF), Belgium. 10.

10. Pyrhönen K, Näyhä S, Läärä E (2015) Dog and cat exposure and respective pet allergy in early childhood. Pediatr Allergy Immunol 26(3): 247-255.

11. Ritz BR, Hoelscher B, Frye C, Meyer I, Heinrich J, et al. (2002) Allergic sensitization owing to 'second-hand' cat exposure in scholls. Allergic 57(4): 357-361.

12. Enberg RN, Shamie SM, McCullough J, Ownby DR (1993) Ubiquitous presence of cat allergen in cat-free buildings: probable dispersal from human clothing. Ann Allergy 70(6): 471-474.

13. Karlsson AS, Renström A, Hedrèn M, Larsson K (2004) Allergen avoidance does not alter airborne cat allergen levels in classrooms. Allergy 59(6): 661-667.

14. De Blay F, Chapman MD, Platts Mills TA (1991) Airborne cat allergen (Fel d 1) Environmental control with the cat in situ. Am Rev Rspir Dis 143(6): 1334-1339.

15. Rosenstreich DL, Eggelston P, Kattan M, Dean Baker, Raymond G salvin, et al. (1997) The role of cockroach allergy and exposure to cockroach allergen in causing morbidity among inner-city children with asthma. N Engl J Med 336(19): 1356-1363.

16. National Asthma Education and Preventive Program (2007) Expert panel report 3 (EPR-3): guidelines for th diagnosis and management of asthma-summary report 2007. J Allergy Clin Immunol 120(5 Suppl): S94-S138.

17. Morgan WJ, Crain EF, Gruchalla RS, George t Corner, Meyer Kattan, et al. (2004) Results of a home-based environmental intervention among urban children with asthma. N Engl J Med 351(11): 1068-1080.

18. Health Effects of Exposure to Environmental Tobacco Smoke, Final Report, Sacramento (2005) Office of Environmental Health Hazard Assessment. CA, USA.

19. Mackay D, Haw S, Ayres JG, Fischbacher C, Pell JP, et al. (2010) Smokefree legislation and hospitalizations for childhood asthma. N Engl J Med 363(12): 1139-1145.

20. Croghan IT, Ebbert JO, Hays JT, Darell R S, Alanna M Chamberlian, et al. (2015) Impact of a countrywide smoke-free workplace law on emergency department visits for respiratory diseases: a retrospective cohort study. BMC Pulm Med 15:6.
21. Been JV, Nurmatov UB, Cox B, Nawrot TS, van Schayck CP, et al. (2014) Effect of smoke-free legislation on perinatal and child health: a systematic review and meta-analysis. Lancet 383(9928): 1549-1560.

22.Zhang S, Li L, Gao W, Wang Y, Yao X, et al. (2016) Interventions to reduce individual exposure of elderly individuals and children to haze: a review. J Thorac Dis 8(1): E62-E68.

23. Kim J, Lim Y, Kim H (2014) Outdoor temperature changes and emergency department visits for asthma in Seoul, Korea: a time-series study. Environ Res 135: 15-20.

24. Ozkaya E, Sogut A, Kücükkoc M, Eres M, Acemoqlu H, et al. (2015) Sensitization pattern of inhalant allergens in children with asthma who are living different altitudes in Turkey. Int J Biometeorol 59(11): $1685-1690$

25. Daniel LC, Boergers J, Kopel SJ, Koinis Mitchell D (2012) Missed sleep and asthma morbidity in urban children. Ann Allergy Asthma Immunol 109(1): 41-46.

26. Camargo CA Jr, Rachelefsky G, Schatz M (2009) Managing asthma exacerbations in the emergency department: summary of the National Asthma Education and Prevention Program Expert Panel Report 3 guidelines for the management of asthma exacerbations. Proc Am Thorac Soc 6(4): 357-366.

27. (2016)ritish Guidelines on the Management of Asthma in Audlts. A national clinical guideline, Ireland.

28. Raherison C, Bourdin A, Bonniaud P, G Deslee, G Gracia, et al. (2016) Updated guidelines (2015) for management and monitoring of adult and adolescent asthmatic patients' (from 12 years and older) of the Societe de pneumologie de langue francaise (SPLF) (summary). Rev Mal Respir 33(3): 271-278.

29. Controlling Your Asthma (2016) American College of Chest Physician and the Chest Foundation, USA.

30. Scadding GK, Durham SR, Mirakian R, Jones NS, Leech SC, et al. (2008) British Society for Allergy and Clinical Immunolog. BSACI guidelines for the management of allergic and non-allergic rhinitis. Clin Exp Allergy 38(1): 19-42.

31. Brozek JL, Bousquet J, Baena Cagnani EC, Bonini S, Canonica GW, et al (2010) Allergic rhinitis and its impact on asthma (ARIA) guidelines: 2010 revision. Global Allergy and Asthma European Network; Grading of Recommendations Assessment, Development and Evaluation Working Group J Allergy Clin Immunol 126(3): 466-476.

\section{Your next submission with Juniper Publishers will reach you the below assets}

- Quality Editorial service

- Swift Peer Review

- Reprints availability

- E-prints Service

- Manuscript Podcast for convenient understanding

- Global attainment for your research

- Manuscript accessibility in different formats

( Pdf, E-pub, Full Text, Audio)

- Unceasing customer service

Track the below URL for one-step submission https://juniperpublishers.com/online-submission.php 